\title{
AUSTIN CLARKE: 'MEMBERING HOME AND THE BLACK ATLANTIC
}

\author{
Winfried Siemerling \\ University of Waterloo
}

\begin{abstract}
In his memoir 'Membering (2015), Clarke employs associative memorial practices as recuperative textual strategies to make himself a $(\mathrm{t})$ home in Toronto and a black Atlantic-cumMediterranean geography and history marked by the afterlife of slavery. "Membering" fragmented histories and fusing personal experience with diasporic dispersals, Clarke's interventionist critical memory imaginatively lays claim to the wealth reaped from diasporic dispossessions, transforming victimization into rightful ownership and a sense of belonging. KeYwords: Austin Clarke, 'Membering, memory, slavery, history, imagination, myth grounded in truth, possession, spirits, home.
\end{abstract}

\section{AUSTIN CLARKE: REMEMBRANDO EL HOGAR Y EL ATLÁNTICO NEGRO}

\section{RESUMEN}

En sus memorias 'Membering (2015), Clarke emplea prácticas asociativas de corte memorístico como estrategias textuales recuperativas para construirse un hogar y sentirse como en casa, tanto en Toronto como en una geografía e historia del Atlántico negro y del Mediterráneo marcadas por las consecuencias de la esclavitud. Remembrando historias fragmentadas y fusionando experiencia personal con dispersiones diaspóricas, la memoria intervencionista de Clarke reivindica imaginativamente la riqueza obtenida de las desposesiones diaspóricas, transformando así la victimización en legítima propiedad y sentido de la pertenencia.

Palabras clave: Austin Clarke, 'Membering, memoria, esclavitud, historia, imaginación, mito basado en la verdad, posesión, espíritus, hogar. 
When Austin Clarke's memoir 'Membering appeared in 2015, I had occasion again to reflect on a writer whose work I had come back to time and again over the years. It was instructive to follow Clarke's early wrestling with Toronto life, to read the entertaining accounts of his Harlem adventures looking for Baldwin but finding -and interviewing-Malcolm X, and of his involvements in politics; and it was enlightening to read the analyses of his own early novels, including his observations on the (lack of) models in that period, on the meaning of literary ancestors, and on CanLit and the Toronto literary scene at the time.

Among these autobiographical and literary riches, however, a short chapter a little after the halfway mark of the text attracted my particular attention. Entitled "The Green Door House," it begins with a reflection -seeming unconnected or even out of place at first as one peruses the following paragraphs- about the singular power of music to conjure, without warning and with great force, a vast amount of memories and emotions that come to the listener with sudden immediacy. Writes Clarke:

I find myself sometimes, at odd moments, with no preparation for my recollection of song, nor any indication that the words of the verses have still remained in my memory; but when these snatches of memories come to me, like a spasm of history, I recall most of the lyrics, and certainly that part which must have struck me as relevant, or personally touching, when first the 'membering of the tune struck me. (251)

The power of the aural also shines forth in an earlier comment by Clarke in the volume; memorizing jazz pieces like Miles Davis' "Flamenco Sketches" (1959) and Coltrane solos in their entirety used to lighten his winter walks in the absence of an unaffordable Walkman (241). Now, however, he cites the uncontrollable, overpowering, and irruptive force of Whitney Houston's "I Wanna Dance with Somebody" (1987). Suddenly, "like a spasm of history," other past instances flood Clarke's memory, and moments where her artistry, like that of Ray Charles on another remembered occasion, seemed to vanquish racial animosity, and signaled to him that "once more a black American was showing the light to the vast, overwhelming white America" (252).

After this opening, the associative registers of the narrative shift from sound to sight, and only later in the chapter and the volume will the connection with the opening reveal itself obliquely -although a sense of the compositional intricacies and frequent tonal re-codings of jazz transitions lingers throughout. The shift is heralded by the chapter title's reference to the colour green. Clarke now recounts his attraction to a house "conspicuous for its green-painted door, cut vertical into two halves, so that only half opened to let you enter; and this house has stood out in my attention because of the way the lights settle on it, in a soft sensual sensation. This house," Clarke continues, "pulled me toward it, in a trance-like communication, to face the spirits and the myths of my history" (252). We could note that the door, cut vertically into half, also limits entrance, blocking as much space as it opens, hiding as much as it reveals, while nonetheless letting you enter. But it is the light that works 
its strong visual effects on Clarke's 'membering and imaginative capability. It does so especially as the sun strikes the house "at the four o'clock angle of romance and seduction" (253) that foreshadows communion with "the spirits and the myths of my history". Some of the associations evoked by that phrase become clearer as the text progresses, but the modular force of light here lets his mind range widely -like a solo by Trane- over a number of locations and recognizable themes, only to come "home," as we will see, in several surprising turns. The evocative force of light takes Clarke to the primordial role it has in Italian painting; and hence to its revelation, on a palazzo wall in Vicenza, of a Roman numeral that in his mind translates into 1492- "the year Christopher Columbus 'discovered' me in Barbados, and others like me, in the Caribbean" (253).

Columbus, we know, did not call on the author in Barbados, while historians will be quick to point out that he also neither 'discovered' nor discovered Barbados (instead of Pedro a Campos in 1536). The nature of Clarke's first statement will perhaps guide us, however, also not to read the second one literally -and in addition to look in a similar way at the somewhat improvised transposition from Roman to Arabic numerals "according to my memory". I will return to this rather important point, but for now suffice it to say that the modular transition to 1492 and Columbus, together with the connecting motive of the blue waves of the sea, allow Clarke to initiate a chain of associations leading his memories through earlier travels, to Havana, Venice, Paris, and finally Bordeaux. The sequence traverses a black Atlantic-cum-Mediterranean geography, guided by a theme that offers an extended meditation on the link between wealth and the slave trade.

Havana's Malecón, facing "the same water that Christopher Columbus travelled", with its dilapidated grandeur reminds Clarke of the city's former splendor; but it also leads him to wonder about "the profits made from the Atlantic trade that came across the Atlantic Ocean" (254). During a subsequent trip to Venice, Clarke marvels about its water-based architecture and magnificence, yet feeling again impelled to ask: "where did all this Venetian wealth come from?" (255). His answer includes not only trickery and trade but, more specifically, the slave trade. Although Venice had other sources of income, it is indeed true that it was active in the Mediterranean slave trade; in an all-important turn, however, Clarke will add: "But this is speculation. I do not have papyrus and old tomes to check against my fancy, and my fantasy. My narrative is built upon the strong foundation of myth. But there is the same pull, the same importance of light, the same hidden spirits in the buildings that surround me, in Toronto; and on the Malecón, and here in Venice. Who has the ownership of this history?" (255).

During a subsequent visit to Bordeaux, Clarke notes that the light on the city's water-facing buildings reminds him of the Malecón; his host surprises him by responding voluntarily: "These buildings you're seeing, all along this way, are the profits from the slave trade" (259). Although speaking "without prompting," the French host seems to have caught the gist of Clarke's earlier musings about light: "It makes me feel I've been here, before. And I know I have not been here before. In a different sense. But I also know I have been here, before" (258). 


\section{1. "IN A DIFFERENT SENSE"}

"In a different sense": one facet of this amplification appears as Clarke remembers a trip to Amsterdam, where he tours the canals. Again it is the light on the canal houses that reminds Clarke of Havana, Venice, Bordeaux, and also of the Wharf in Barbados' Bridgetown: "All this history and history of architecture here in the Netherlands is bound up in slavery. 'Bound up' is the ironical intransitive verb. My history touches all of them: buildings in which I was tied up and flogged, but in which my spirits lived on" (261). Clarke's use of the pronoun "I" tells us that, before physically arriving in Bordeaux for instance, he feels he has been there indeed, in a metonymic sense that also nourishes Langston Hughes's speaker in "The Negro Speaks of Rivers" -an all-encompassing "I" that has witnessed waterways and civilizations from a black perspective, and that has retained, accumulated, and remembered the significance of that presence and experience (Hughes 4).

But there is a further facet of this "different sense" evoked by Clarke, a sense that comes to the fore in connection with the green-door house. Clarke has mentioned the house also in the context of the other cities, adding at some point that he finally bought it and added a green awning over the green door (Clarke 258). We learn that he is "thinking that this house, the one with the green door, built in 1863 , could have been the residence of a man who fled to Canada, on the Underground Railroad, and who became 'a shoemaker.' And I turn the pages of history and of speculation faster," Clarke adds, "in order to get to the narrative of myth grounded in truth. And to see whose truth I am using; and whose truth it is" (259). What Clarke is telling us is that the "narrative of myth," which in his memory leads across so many water-connected locations like a jazz musician's solo across key and chord changes, is "grounded" in a certain kind of positional truth that is not limited by facts; as he explains, "I add to the 'facts' of that history, the real truth, the 'narrative' coached by the spirits and the myths, and I conclude that the man who lived in this green-door house, in 1876, three years after it was built, was a slave " (261). Clarke tells us that he bought the house after having passed it for fourteen years, and wonders whether the slave who became a shoemaker could "deliberately, and from the grave, have sent those spirits to alert me, and have me join them?" (262).

There is a sense of a homecoming here as the chapter modulates back to its opening motives of voice-and-light-induced memory and of the green-door house's ability to pull the author, "in a trance-like communication, to face the spirits and the myths of my history" (252). The force field of that "trance-like communication" has indeed determined the composition of the chapter, with its modal transitions ranging in transformative ways, and "in a different sense," across the reigns of factuality and truth. Clarke in his own distinctive style does here what other writers have done in their own ways to get to the bottom of things, and with the help of an imagination "grounded in truth" extract and create meaning from the multiform surfaces and appearances of reality. Clarke's reference to light, romance, and seduction, for instance, evoke the seductive effects that Nathaniel Hawthorne, in "The Custom House," ascribed to the moonlight, a medium which for him "spiritualized" the daily objects around him and was "the most suitable for a romance- 
writer to get acquainted with his illusive guests" (and ghosts), creating a space "where the Actual and Imaginary may meet, and each imbue itself with the nature of the other" (24). The text Hawthorne thus introduced, The Scarlet Letter (1850), also explored deeper historical truths with the help of a wide-ranging imagination. Clarke's distinction between "facts" and "the real truth" also evokes, however, Toni Morrison's reflections on this matter; as she writes in "The Site of Memory" (1995), "the crucial distinction for me is not the difference between fact and fiction, but the distinction between fact and truth. Because facts can exist without human intelligence, but truth cannot" (93). And if we want to home in further on Clarke's specific handling of the communicative traffic between meaning and the past, his ending reminds us of the more possessive force of the particular spirits that are active in his chapter, and which continue to "ride" him, as he says: those spirits call him to his green-door house, a home whose vertically divided door also opens on the black Atlantic and its history. These possessive spirits are of Caribbean ancestry, as becomes clear when Clarke refers here to his mother's knowledge about "slavery and skeletons and witchcraft"; accepting this knowledge, Clarke concludes his chapter with the assertion that the "shoemaker's spirits ride me across the Atlantic Ocean, to the Malecón, to Venice, to Bordeaux, and now to Amsterdam” (262).

\section{HOME}

Yet it is not only that the improvisational journey of Clarke's chapter "homes" back to the opening motives of the evocative force of light and the pervasive yet often surprising presence of memory; the chapter also speaks about a house that Clarke made his home. At a first glance, the "vertical" dimension of this home reveals an "unhomely" and gruesome reality: "So, each time I enter the right-hand half of the green door of the house, built in 1863, I think of all those other houses in Cuba in the Caribbean, in Bordeaux in France, in Venice in Italy, and in Amsterdam in the Netherlands, erected from the help of my sweat and floggings, from the bones in the basements with skeletons" (261). The house thus succeeds indeed in making him face "the spirits and the myths of my history"; but this space also turns out to be home.

Here Clarke surprises us with another turn in his associative journey, a further modulation that makes space, in his "myth grounded in truth," for both the historical consequences of slavery and a notion of home. While referring at length to the brutality of French slavery in Haiti, Clarke can nonetheless write: "I am home in Paris". The city for him "reflects a relationship, that, in spite of its viciousness and its inequalities [...] involved me, in presence, in colour, in voice, and ironically, in labour and the profits made from my labour." As a consequence, Clarke comes to "think of the most foreign and unusual cities, as home. Havana. Toronto. Venice. Manchester. Bordeaux. Toulouse. Amsterdam. Paris. (257). With this distinctive turn, Clarke takes personal possession of the "myths of my history." He lays claim to the wealth and splendor created by the enslaved, in a perspective that transforms victimization into rightful ownership. In a subsequent chapter that returns to some of these motives, "The Culture of Chains," Clarke makes this re-coding of memory 
-a constant presence evoked by sound, light, and a "vertical" imagination- even more explicit. Recalling his visit to Amsterdam a second time, he remembers traveling its canals "in such a way that I feel I am going through the intestines of a city that fed upon the land and upon the people that came from islands in my part of the world; and in this shocking realization, I am not angry, I am not ashamed, I am not feeling as if I am a victim. I feel I am a partner. A senior partner. It was my 'wealth' of skin and sweat and culture that made the 'wealth' of Amsterdam and the Netherlands" (278).

Clarke's re-coding of the associations of victimization into a perspective that includes not just proprietorship, but indeed senior partner status with its concomitant claims to control, reveals a way of living "in the wake" (Sharpe) that also articulates insistent forms of belonging; it is a narrative "built upon the strong foundation of myth" that claims ownership of history as a form of home (but may also yet continue to be present in claims for material reparations). Hortense Spillers is among those who have tried to spell out the stakes and challenges in changing the kinds of myth that Clarke's 'membering is working to transform. Certain designations, writes Spillers, "are markers so loaded with mythical prepossession that there is no easy way for the agents buried beneath them to come clean. [...]. In order for me to speak a truer word concerning myself, I must strip down through layers of attenuated meanings, made an excess in time; over time, assigned by a particular historical order, and there await whatever marvels of my own inventiveness" (Spillers 203). Clarke's celebratory meditation and memory-driven improvisation on the motive of the green-door house put the "marvels" of his "own inventiveness" to incisive use. In the process of "membering," we see Clarke make himself a $(\mathrm{t})$ home in Toronto and its history while connecting his experiences to a transnational sense of belonging that manages to distill resilience and pride from a history of dispersal and devastation. Having taken possession of his abode, and responding in "trancelike communication" to the spirits of history in acts of "membering that bring forth transformative "myth grounded in truth," Clarke in the end "knew that I was wise in purchasing the green-house door" (260).

Reviews sent to author: 15 October 2018 Revised paper accepted for publication: 22 November 2018 


\section{WORKS CITED}

Clarke, Austin. 'Membering. Toronto: Dundurn, 2015. Print.

Hawthorne, Nathaniel. The Scarlet Letter. Mineola, New York: Dover, 1994. Print.

Hughes, Langston. “The Negro Speaks of Rivers.” Selected Poems of Langston Hughes. New York: Vintage Classics, 1990. Print.

Morrison, Toni. "The Site of Memory." Inventing the Truth: The Art and Craft of Memoir. Ed. William Zinser. (Revised and Expanded Second Edition). Boston and New York: Houghton Mifflin, 1995. 85-102. Print.

Sharpe, Christina. In the Wake: On Blackness and Being. Durham and London: Duke UP, 2016. Print.

SpIllers, Hortense J. Black, White, and in Color: Essays on American Literature and Culture. Chicago and London: University of Chicago Press, 2003. Print. 
